\title{
Allergic diseases of the skin and drug allergies - 2028. Vitamin D insufficiency in dress syndrome
}

\author{
Young-Hee Nam", II-Hwan Jeong, Hye-Won Lee, Neul-Bom Yoon, Soo-Jung Um, Choon-Hee Son, Soo-Keol Lee
}

From 2nd WAO International Scientific Conference (WISC 2012)

Hyderabad, India. 6-9 December 2012

\section{Background}

Vitamin D deficiency (VDD) is widespread and on the increase. A few reports showed VDD has been implicated cutaneous symptoms such as rash and urticaria/angioedema and drug reaction with eosinoophilia and systemic symptoms (DRESS). We evaluated the association of serum 25-hydroxyvitamin D3(25[OH]D3) and DRESS.

\section{Methods}

36 patients diagnosed as DRESS were prospectively collected from September 2010 to April 2012. The diagnostic criteria in this study was used from our previous report.

\section{Results}

Study patients consisted of 16 men (44.4\%) and 13 women (55.6\%). The most common causative drugs were antibiotics $(17,47.2 \%)$ and anticonvulsants $(9,25 \%)$, followed by non-steroidal anti-inflammatory drugs $(5,13.2 \%)$, antituberculosis drugs $(4,11.1 \%)$, undetermined agents $(4,8.9 \%)$, others $(2,5.6 \%)$ and undetermined $(2,5.6 \%)$. The mean serum 25[OH]D3 level of the total subjects was $11.96 \pm$ $10.27 \mathrm{ng} / \mathrm{ml}$. Thirty-five patients (97.2\%) had low vitamin D levels; 19 were severe VDD $(<10 \mathrm{ng} / \mathrm{mL}$, group \pm$)$, and 16 vitamin $\mathrm{D}$ insufficiency $(10-30 \mathrm{ng} / \mathrm{mL}$, groupII). The mean serum 25[OH]D3 level of each group was $7.02 \pm$ $1.65 \mathrm{ng} / \mathrm{ml}$ and $14.46 \pm 3.56 \mathrm{ng} / \mathrm{ml}$, respectively.There were no significant differences in sex, age, culprit drugs, organ involvements and the use of systemic steroids between two groups, except admission days ( $96.21 \pm 89.66$ vs. $37.56 \pm 40.43, \mathrm{p}=0.034)$. The level of serum $25(\mathrm{OH}) \mathrm{D} 3$ was inversely correlated with admission days $(r=-0.387$, $\mathrm{p}=0.02$ ).

Department of Internal Medicine, College of Medicine, Dong-A University, Busan, South Korea

\section{Conclusions}

Vitamin D insufficiency was noted in patients with DRESS. Further studies are needed in large samples and to evaluate the vitamin D roles in drug hypersensitivity.

Published: 23 April 2013
Submit your next manuscript to BioMed Central and take full advantage of:

- Convenient online submission

- Thorough peer review

- No space constraints or color figure charges

- Immediate publication on acceptance

- Inclusion in PubMed, CAS, Scopus and Google Scholar

- Research which is freely available for redistribution
C Biomed Central 